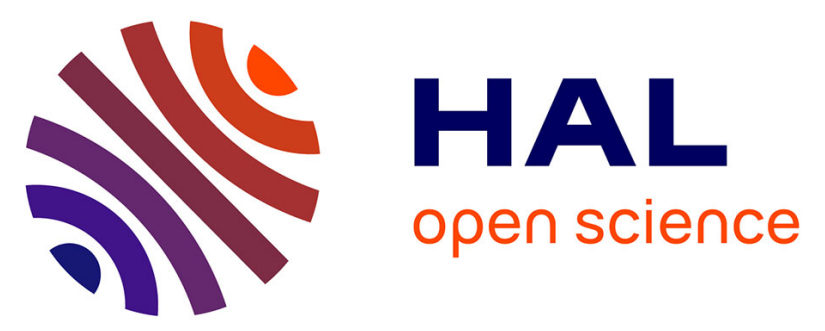

\title{
Evaluation of the genotoxic and teratogenic potential of a municipal sludge and sludge-amended soil using the amphibian Xenopus laevis and the tobacco: Nicotiana tabacum L. var. xanthi Dulieu
}

Pascale Chenon, Laury Gauthier, Pascale Loubières, Alain Séverac, Marcel Delpoux

\section{To cite this version:}

Pascale Chenon, Laury Gauthier, Pascale Loubières, Alain Séverac, Marcel Delpoux. Evaluation of the genotoxic and teratogenic potential of a municipal sludge and sludge-amended soil using the amphibian Xenopus laevis and the tobacco: Nicotiana tabacum L. var. xanthi Dulieu. Science of the Total Environment, 2003, vol. 301, pp. 139-150. 10.1016/S0048-9697(02)00287-5 . hal-00753297

\section{HAL Id: hal-00753297 \\ https://hal.science/hal-00753297}

Submitted on 19 Nov 2012

HAL is a multi-disciplinary open access archive for the deposit and dissemination of scientific research documents, whether they are published or not. The documents may come from teaching and research institutions in France or abroad, or from public or private research centers.
L'archive ouverte pluridisciplinaire HAL, est destinée au dépôt et à la diffusion de documents scientifiques de niveau recherche, publiés ou non, émanant des établissements d'enseignement et de recherche français ou étrangers, des laboratoires publics ou privés. 


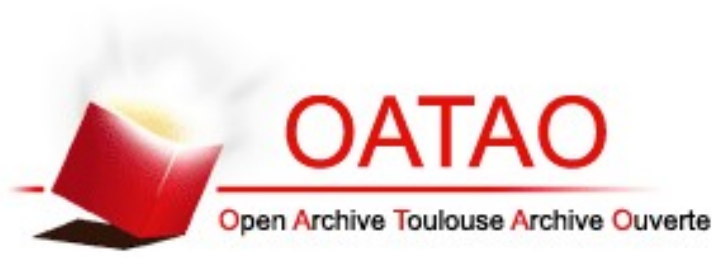

\section{Open Archive Toulouse Archive Ouverte (OATAO)}

OATAO is an open access repository that collects the work of Toulouse researchers and makes it freely available over the web where possible.

This is an author-deposited version published in: http://oatao.univ-toulouse.fr/ Eprints ID: 5735

To link to this article: DOI:10.1016/S0048-9697(02)00287-5

http://dx.doi.org/10.1016/S0048-9697(02)00287-5

To cite this version: Chenon, Pascale and Gauthier, Laury and Loubières, Pascale and Séverac, Alain and Delpoux, Marcel Evaluation of the genotoxic and teratogenic potential of a municipal sludge and sludge-amended soil using the amphibian Xenopus laevis and the tobacco: Nicotiana tabacum L. var. xanthi Dulieu. (2003) Science of the Total Environment, vol. 301 (n¹-3). pp. 139-150. ISSN 0048-9697

Any correspondence concerning this service should be sent to the repository administrator: staff-oatao@inp-toulouse.fr 


\title{
Evaluation of the genotoxic and teratogenic potential of a municipal sludge and sludge-amended soil using the amphibian Xenopus laevis and the tobacco: Nicotiana tabacum L. var. xanthi Dulieu
}

\author{
Pascale Chenon, Laury Gauthier*, Pascale Loubières, Alain Séverac, Marcel Delpoux \\ Centre Universitaire Jean-François Champollion, place de Verdun, 81012 Albi cedex 9, France
}

\begin{abstract}
The toxic, genotoxic and teratogenic potential of a municipal sewage sludge was assessed using the micronucleus assay on the larvae of the amphibian Xenopus laevis and with the tobacco somatic mutation test using the yellowgreen xanthi Dulieu mutant $a_{1}^{+} / a_{1} a_{2}^{+} / a_{2}$. The teratogenic potential was assessed by means of the Frog Embryo Teratogenesis Assay-Xenopus (FETAX). Various doses of the pasty sludge added to a crop soil were tested using the three bioassays. The test systems were performed either directly with sludge or sludge-amended soil samples (plant model) or with aqueous extracts (aquatic animal model). Using the tobacco model, we found no mutagenic impact of the soil amended with the sludge, perhaps because the clay-like nature of the soil, with its high adsorption capacity, may have prevented the contaminants from reaching the target. All leachates of amended soils produced a significant size reduction in Xenopus embryos. Depending on the soil/sludge ratio, some leachates were found to be genotoxic but were never teratogenic. This battery of in vivo test systems enabled us to estimate the global long-term effects under agricultural conditions with various genetic endpoints on ecologically relevant organisms characteristic of the aquatic and terrestrial compartments.
\end{abstract}

Keywords: Genotoxicity; Teratogenicity; Sludge; Sludge-amended soil; Amphibian; Xenopus; Tobacco; Micronucleus assay; FETAX.

\section{Introduction}

The management of sewage sludge is becoming

\footnotetext{
*Corresponding author. Present address: Centre de Biologie du Développement, UMR 5547 du CNRS, affiliée à 1'INSERM, Université Paul Sabatier, 118 route de Narbonne, 31062 Toulouse Cedex, France. Tel.: + 33-5-61-55-67-38; fax: +33-5-61-55-65-07.

E-mail address: laury.gauthier@cict.fr (L. Gauthier).
}

of ever greater concern since the generated volume is increasing as a result of extended sewerage and advanced wastewater treatments. Sludge is a valuable source of plant-available nutrient and organic matter and has been recycled as a fertilizer on agricultural land. However, these sludges may be contaminated by toxic and persistent chemicals; hence, the agricultural use of sludge implies that the pollutants, redispersed into the environment 
via surface soils, may eventually enter the food chain. Persistent polar compounds, which are less strongly absorbed by the soil, may reach the aquifer and thus pollute groundwater (Klöpffer, 1996). Sludge could thus contain thousands of different compounds, organic and inorganic, derived from domestic sewage and industry.

Since it is impossible to identify all the contaminants in sludge, the global ecotoxicological impact assessment of waste and sludge samples using different types of bioassays has been proposed. Among the ecotoxicological bioassays, those able to detect long-term impacts, such as mutagenic or teratogenic effects, are of particular interest for environmental studies. Indeed, some mutations may affect the germ cells, with dramatic consequences at the population level. Under other conditions, some mutations may lead to the development of cancers in the exposed organisms.

To evaluate genetic damage in the environment, the most commonly used assays are based on bacteria, such as the Ames test (Ames et al., 1975; Maron and Ames, 1983). The main advantages are that such tests can be carried out rapidly and cheaply. However, one of the main drawbacks of these bacterial test systems for the detection of genotoxic substances in water is that they are relatively insensitive and in general they cannot be used on unconcentrated water samples (Weaver et al., 1981; Gauthier et al., 1993).

Ideally, one should evaluate the biological hazards of environmental genotoxic pollutants in situ. In vivo mutagenicity tests applied to unconcentrated water samples represent a step in this direction (Jaylet and Zoll, 1990; Van Der Gaag et al., 1990). They give an ecologically relevant indication of the overall genotoxic potential of a water sample with respect to a whole living organism (Gauthier et al., 1993).

In this work, two different biological models have been used to detect the in vivo genotoxic potential of sludge and sludge-amended soil samples: the amphibian Xenopus laevis and the tobacco plant Nicotiana tabacum L. var. xanthi-Dulieu. Using the Xenopus model, two standardized test methods have been applied to aqueous extracts of sludge and soil-sludge mixtures: the micronucleus test (MN-test), adapted to larvae and the Frog
Embryo Teratogenesis Assay-Xenopus (FETAX test) on embryos. Usually, the genotoxic potential of soil samples is directly evaluated using plant models, more relevant to agronomic conditions. In the present study, we have compared the genotoxicity of sludge and soil samples measured with the amphibian model to the genotoxic potential evaluated with the Tobacco Somatic Mutation Test.

\section{Materials and methods}

\subsection{Sludge and soil sampling, preparation of leachates and mixtures}

The sludge (S) was partially dehydrated $(20 \%$ dry matter). After production, the liquid sludge was flocculated with zetag polymer $(6 \mathrm{~kg} / \mathrm{t} \mathrm{dm})$ and centrifuged in a 'Guinard centrifuge' at the water treatment plant. Two separate batches of the sludge (S1 and S2) were sent to the laboratory and tested. A crop soil (So), from an experimental farm, was used as diluent in the soil-sludge mixtures. It is a brown chalky soil representative of the alluvial soils of north-eastern France. Soil and sludge samples were stored at $4{ }^{\circ} \mathrm{C}$ in the dark before use.

Aqueous extracts (Sludge Leachate SL and Soil Leachate SoL) were performed according to the French standard X31-210 (AFNOR, 1992), without filtration. In the first series of experiments, the sludge was added in a 60-1 plastic tank (sludge/ water ratio: 1/10). After mixing with a rotor $(24$ $\mathrm{h}, 300 \mathrm{rpm}$ at room temperature) and decantation $(24 \mathrm{~h})$, the supernatant was sampled and stored at $4{ }^{\circ} \mathrm{C}$ before dilution and testing. In the other experiments, the leachates were performed after determination of the dry matter $\left(48 \mathrm{~h}, 80{ }^{\circ} \mathrm{C}\right)$ in the substrate samples. Tobacco plants were directly exposed to the substrates. Soil-sludge mixtures were produced at $25 \mathrm{rpm}$ for $10 \mathrm{~min}$ in a 100-1 mixer and stored at room temperature before testing. Mixture concentrations are expressed as tons of dry matter per hectare (tdm/ha).

In the framework of this study, physico-chemical analyses of the substrates and plants were performed by the Hydrological and Environmental Research Institute of Nancy, France. 


\subsection{The Xenopus micronucleus assay}

Originally, the test procedure was established in our laboratory on the anuran Xenopus laevis (the South African clawed frog or common platanna; family Pipidae) by Van Hummelen et al. (1989) and Zoll et al. (1990). The test is particularly suitable for evaluating promutagens and genotoxic agents with a direct action, as well as environmental complex mixtures such as urban and industrial effluents (Zoll-Moreux, 1991; Zoll-Moreux and Ferrier, 1999). Furthermore, their abundant egglaying, the availability of larvae throughout the year and their consumption of standardized dehydrated food confer certain advantages to Xenopus over the urodeles (Gauthier, 1996).

The test procedure used in this study was described in the French Standard NF T 90-325 (AFNOR, 2000). Briefly, it consists of the evaluation of the number of micronucleated red blood cells (RBCs) in larvae exposed for 12 days at $22 \pm 0.5{ }^{\circ} \mathrm{C}$ under a normal light-dark cycle. The larvae are exposed by groups of 15 animals in 5-1 glass flasks containing 1.51 of water $(100 \mathrm{ml}$ per larva). The test begins on larvae at stage 50 of the chronological development table of Xenopus (Nieuwkoop and Faber, 1956). Throughout the period of exposure, the media are renewed daily (water and food). In the experiments described here, positive and negative controls were included in each experiment. The negative control was water filtered over sand and active charcoal, supplemented with mineral salts. The positive control was a $20 \mathrm{mg} / 1$ solution of cyclophosphamide monohydrate. After exposure, blood samples were taken from each larva by cardiac puncture and one smear was prepared per animal. After fixing in methanol and staining with hematoxylin, the smears were screened under the microscope (oil immersion lens, $\times 1500)$. The RBCs that contained one or more micronuclei were counted in a total sample of 1000 erythrocytes per larva. For each animal, the mitotic index (number of mitotic erythrocytes per 1000) was evaluated by scoring the dividing cells of the circulating blood on the smears.

For each group of animals, the results (level of micronucleated RBCs per 1000) obtained for the individual larvae were arranged in increasing order of magnitude and the medians and quartiles calculated. The statistical method used to compare the medians was based on the recommendations of Mac Gill et al. (1978). It consists in determining the theoretical medians of samples of size $n$ (where $n \geq 7$ ) and their $95 \%$ confidence limits expressed by $M \pm 1.57 \times \mathrm{IQR} / \sqrt{ } n$, where $M$ is the median and $\mathrm{IQR}$, the Inter Quartile Range. Under these conditions, the difference between the theoretical medians of the test groups and the theoretical median of the control group is significant to within $95 \%$ certainty if there is no overlap. The result is then positive.

\subsection{The Frog Embryo Teratogenesis Assay-Xeno- pus (FETAX)}

\subsubsection{Solutions for the bioassay}

FETAX solution is (in $\mathrm{mg} / \mathrm{l}$ ): $\mathrm{NaCl}$ (625), $\mathrm{NaHCO}_{3}$ (96), $\mathrm{KCl}$ (30), $\mathrm{CaCl}_{2}$ (15), $\mathrm{CaSO}_{4^{-}}$ $2 \mathrm{H}_{2} \mathrm{O}(60)$ and $\mathrm{MgSO}_{4} 2 \mathrm{H}_{2} \mathrm{O}(70)$ at $\mathrm{pH} 7.8 \pm 0.2$. Barth's solution without $\mathrm{Ca}^{2+}$ is (in $\mathrm{g} / 1$ ): $\mathrm{NaCl}$ (256.5), $\mathrm{KCl}$ (3.74), $\mathrm{NaHCO}_{3}$ (10.1), $\mathrm{Na}_{2} \mathrm{HPO}_{4}$ (14.2), $\mathrm{KH}_{2} \mathrm{PO}_{4}$ (0.68), EDTA (9.3) at $\mathrm{pH} 8.5-$ 8.8 .

\subsubsection{In vitro fertilization}

Adult Xenopus were produced in the laboratory and fed with minced beef heart. For a single bioassay, six adult females were injected with 450 IU of human chorionic gonadotrophin (hcg 500 IU, Organon/Ditrireti). Approximately $16 \mathrm{~h}$ later, each female was induced to lay eggs in a plastic Petri dish, which was immediately inseminated with sperm suspension previously obtained by mincing adult male testes in 1-2 $\mathrm{ml}$ of cold Barth's solution without $\mathrm{Ca}^{2+}$. One minute later, $10 \mathrm{ml}$ of FETAX solution was added to each petri dish. Successful insemination was identified when, after a few minutes, all the eggs were oriented with the dark animal pole side upwards. A first screening performed $5 \mathrm{~h}$ post fertilization (p.f.) enabled us to remove the unfertilized and necrotic eggs. This was followed by a final screening, $8 \mathrm{~h}$ p.f. (stage 8 , blastulae), in which normal cleavage 
and development were ascertained (Nieuwkoop and Faber, 1956). Then the selected normal embryos were placed in a series of $60-\mathrm{mm}$ plastic petri dishes, in duplicates ( 8 embryos per $10 \mathrm{ml}$ of medium per dish) for the control and exposed groups. $\mathrm{ZnSO}_{4}$ at a concentration of $70 \mathrm{mg} / 1$ was used as positive control, because this substance of environmental interest was found in the laboratory to be highly teratogenic at this concentration, but not toxic. All test solutions were administered from stage 8 to 47 , over a period of $112 \mathrm{~h}$. Plates were incubated in a thermostatic chamber at $23 \pm 0.5{ }^{\circ} \mathrm{C}$ and the medium renewed daily. Dead embryos were removed at this time. If the mortality and malformation levels in the control group of each female were more than $20 \%$, all the rest of experimental group was discarded (Bernardini et al., 1994).

\subsubsection{Data collection}

After 120 h p.f., dead embryos were scored under a binocular, using as main criterion the absence of heartbeat and mobility. The surviving embryos were anaesthetized with tricaine methane sulfonate (MS 222, Sandoz) and evaluated for growth inhibition and malformations. The headtail length was measured for all normal embryos.

The rates of mortality and malformation in each treated groups were compared statistically to the negative control using the $z$-test $(P=0.05)$. The head-tail length data were used to calculate a value for the minimum concentration to inhibit growth (MCIG) using ANOVA $(P=0.05)$.

\subsection{The tobacco somatic mutation test}

The biological material used was the $a_{1}^{+} / a_{1}$ $a_{2}^{+} / a_{2}$ system of the tobacco Nicotiana tabacum L. var. xanthi n.c. that has been described elsewhere (Dulieu, 1975; Dulieu and Dalebroux, 1975). In this study, this mutant tobacco was called $N$. tabacum var. xanthi Dulieu. The two loci $a_{1}$ and $a_{2}$ are involved in chloroplast differentiation without intercellular metabolic cooperation and the double heterozygote $a_{1}^{+} / a_{1} a_{2}^{+} / a_{2}$, partially chlorophyll-deficient, has greenish-yellow leaves. Either spontaneously or under the action of chemical or physical mutagens, the genetic composition of the double heterozygous system can be modified, yielding mostly reverted green cells; the frequency of modifications to white and yellow cells is negligible and, hence, may be disregarded (Fabries and Delpoux, 1978). As an individual grows, each reverted cell yields a clone that appears as a green spot in the palisade tissue of the greenish-yellow leaf. Because a very large number of cells can be observed in a single individual (1000-2000 cells $/ \mathrm{mm}^{2}$ of leaf), this marker system is particularly appropriate for the detection of genetic effects of low and very low doses of radiations (Delpoux and Dalebroux, 1981a,b) and of atmospheric pollutants (Devaud, 1986) with very good statistical precision.

Tobacco plants were produced in vitro in the laboratory using culture medium 169 (Murashige and Skoog solutions supplemented with EDTA-Fe and biotin at $\mathrm{pH} 5.5$ ). At the 6-8 leaf stage, the plants were grown in a greenhouse receiving filtered air (over a synthetic filter and activated charcoal) under constant overpressure. Each plant was placed in a pot filled with the sludge, with the agricultural soil, or with the soil-sludge mixture to be tested. Eighteen plants were cultivated for each concentration. After a long period of exposure (approx. 45 days), 3 adult leaves were taken from each plant and examined under a binocular magnifying glass to score the reverted sectors. The genetic effects of the different culture conditions were expressed as average reversion rates per cell cycle on the bases of the number of reverted cells or, equivalently, of reverted leaf areas. It has been shown (Dulieu and Dalebroux, 1975) or repeated (Fabries and Delpoux, 1978) that for a given individual, there exists a simple relationship between the total leaf area $S$ and the reverted area $S_{g}$ on the one hand and the reversion rate $p$ on the other: $p=1-\left[\left(S-S_{g}\right) / S\right]^{1 / t}$, where $t$ is the number of cell cycles that occurred during the exposure of the tobacco plants. Because spots smaller than $0.05 \mathrm{~mm}^{2}$ cannot be detected by the observation method used (Fabries and Delpoux, $1978), t$ is equal to $[\log N / \log 2]-7 . N$ is the total number of cells observed that corresponds to the total leaf area $S$, with cell density $d$ (number of cells per unit area), so that $N=d S$. 
Table 1

Xenopus micronucleus assay results. Toxicity and genotoxicity of sludge S1, evaluated after aqueous extraction and dilution of the leachate (SL1) in water. First experiment

\begin{tabular}{|c|c|c|c|c|c|c|c|c|c|}
\hline & Negative control & Positive control & $15.62 \mathrm{ml} / 1$ & $31.25 \mathrm{ml} / 1$ & $62.5 \mathrm{ml} / 1$ & $125 \mathrm{ml} / 1$ & $250 \mathrm{ml} / 1$ & $500 \mathrm{ml} / 1$ & $1000 \mathrm{ml} / 1$ \\
\hline$M$ & 2 & 6 & 3 & 4 & 4 & 6.5 & 5 & ND & ND \\
\hline $\mathrm{CL}$ & {$[1.2-2.8]$} & {$[4.1-7.9]$} & {$[2.3-3.7]$} & {$[2.9-5.1]$} & {$[3.3-4.7]$} & {$[5.8-7.2]$} & [3.9-6.1] & ND & ND \\
\hline Results & & + & - & + & + & + & + & ND & ND \\
\hline Toxicity & NT & NT & NT & NT & NT & NT & $\mathrm{T}$ & HT & HT \\
\hline
\end{tabular}

Genotoxicity results are expressed as the values of the medians $M$ (number of micronucleated erythrocytes per thousand) and their $95 \%$ confidence limits [CL]. ND: Not Determined. -: Negative results, no genotoxic effects detected in the tested groups. + : Positive results, genotoxic effects detected in the tested groups.

Toxicity results. HT: Highly toxic, all animals in the groups were dead. T: Toxic, all animals in the groups showed significant size reduction. NT: Not toxic, no toxicity observed in the groups.

\section{Results}

\subsection{Bioassays using the amphibian Xenopus laevis}

\subsubsection{The micronucleus assay}

Two separate experiments were carried out on different supplies of sludge ( $\mathrm{S} 1$ and S2). The main goal of the first one (S1) was to evaluate the ability of the Xenopus micronucleus assay to reveal the genotoxic potential of urban sludge. In this case, the leachate was produced directly from the fresh sludge (ratio 1/10). The leachate (SL1) and appropriate dilutions $(500,250,125,62.5,31.25$ and $15.625 \mathrm{ml} / \mathrm{l}$ ) were tested. The results are shown in Table 1.

The sludge leachate was found to be highly toxic towards the Xenopus larvae. The highest concentrations tested (500 and $1000 \mathrm{ml} / \mathrm{l}$ ) were not evaluated for genotoxicity because of the rapid death of the animals. At $250 \mathrm{ml} / \mathrm{l}$, the sludge leachate was found to be toxic (only small larvae survived), but allowed survival of sufficient animals to perform the micronucleus assay. At this concentration, the micronucleus assay gave a positive response, demonstrating the genotoxic potential of the sludge leachate. At higher dilutions $(125,62.5$ and $31.25 \mathrm{ml} / 1)$, the Xenopus micronucleus assay once more gave positive responses, demonstrating that the sensitivity of the test was adequate to reveal the genotoxic potential of the municipal sludge leachate, even after dilution. The lowest concentration tested $(15.625 \mathrm{ml} / \mathrm{l})$ produced a negative result. With this first assay we demonstrated the ability of the test to highlight the genotoxic potential of an urban sludge leachate, even after considerable dilution in water $(31.25$ $\mathrm{ml} / \mathrm{l})$.

In a second experiment, a new supply of sludge (S2) was mixed with an agricultural soil at different concentrations (equivalent to 10,30, 900 and $3750 \mathrm{tdm} / \mathrm{ha}$ ) to mimic the normal field-amendment conditions in agriculture. The concentration of $30 \mathrm{tdm} /$ ha corresponds to the recommended legal maximum concentration of sludge incorporated into agricultural soil for 10 consecutive years, in France. The concentration of $3750 \mathrm{tdm} / \mathrm{ha}$ corresponds to that of the dehydrated sludge alone, without any addition of soil. For each substrate concentration, a leachate (SL2) was produced after evaluation of the dry matter of the mixture (SoL, SL2-10, SL2-30, SL2-900 and SL2-3750). The leachates were tested for toxicity and genotoxicity on amphibian larvae (Table 2). Because Xenopus larvae did not survive in the leachates SL2-900 and SL2-3750, dilutions were performed at 500, 250,125 and $62.5 \mathrm{ml} / 1$ for both leachates and $31.25 \mathrm{ml} / 1$ for SL2-3750. Under these conditions, the animals did not survive in the leachate SL23750 at the highest concentration level tested (500 $\mathrm{ml} / \mathrm{l}$ ) and their growth was severely inhibited at half this concentration (Table 3). The same growth inhibition effect was observed with leachate SL2900 at $500 \mathrm{ml} / 1$. Positive genotoxic responses were found with leachates of the following soilsludge mixtures: SL2-3750 (62.5 and $125 \mathrm{ml} / \mathrm{l})$ and SL2-30. Negative responses were obtained with leachates of the mixture SL2-10, with all dilution levels of the mixture SL2-900 and with 
Table 2

Xenopus micronucleus assay results. Toxicity and genotoxicity of sludge S2, of soil So and of soil-sludge mixtures at different concentration levels, evaluated after aqueous extraction. Second experiment

\begin{tabular}{llllllll}
\hline & Negative control & Positive control & SoL & SL2-10 & SL2-30 & SL2-900 & SL2-3750 \\
\hline$M$ & 1 & 18.5 & 2 & 2 & 2.5 & ND & ND \\
CL & {$[0.5-1.5]$} & {$[2-35]$} & {$[0.7-3.3]$} & {$[1.1-2.9]$} & {$[1.6-3.4]$} & ND & ND \\
Results & & + & - & - & + & ND & ND \\
Toxicity & NT & NT & NT & NT & NT & HT & HT \\
\hline
\end{tabular}

Genotoxicity results are expressed as the values of the medians $M$ (number of micronucleated erythrocytes per thousand) and their $95 \%$ confidence limits [CL]. ND: Not determined. -: Negative results, no genotoxic effects detected in the tested groups. + : Positive results, genotoxic effects detected in the tested groups.

Toxicity results. HT: Highly toxic, all animals in the groups were dead. T: Toxic, all animals in the groups showed significant size reduction. NT: Not toxic, no toxicity observed in the groups.

two dilutions (31.25 and $250 \mathrm{ml} / \mathrm{l})$ of leachate SL2-3750. The soil leachate (SoL) was not genotoxic in our test system (Table 2).

\subsubsection{The FETAX test}

All experiments using the FETAX test were carried out with the leachate of the second batch of sludge (SL2). The results shown in Tables 4 and 5 resume the experimental data obtained in several FETAX assays. In this study, all the larvae scored as normal were measured. The mean headtail lengths in groups of treated larvae were calculated and compared to the negative control groups. The mean head-tail lengths for different SL2 concentrations are expressed as a percentage of the negative control. Mortality and malformation parameters are presented as percentages in the groups.

The mortality and malformation in the negative control groups ranged from 0 to 10.4 and 0 to $9.4 \%$, respectively. In positive controls, $\mathrm{ZnSO}_{4}$ at $70 \mathrm{mg} / \mathrm{l}$ induced a high level of malformed larvae, from 93.8 to $100 \%$. Significant mortality rates were observed with leachates SL2-900 and SL23750 down to concentrations of $250 \mathrm{ml} / 1$ and 125 $\mathrm{ml} / 1$, respectively. We found no significant mortality in the other leachates or dilutions tested. As for teratogenic effects, in leachate SL2-900 at a concentration of $250 \mathrm{ml} / 1$, all surviving larvae were malformed. Significant malformation levels

Table 3

Xenopus micronucleus assay results. Toxicity and genotoxicity of soil-sludge mixtures SL2-900 and SL2-3750 after water dilution. Second experiment

\begin{tabular}{|c|c|c|c|c|c|c|c|}
\hline & Negative control & Positive control & $31.25 \mathrm{ml} / 1$ & $62.5 \mathrm{ml} / 1$ & $125 \mathrm{ml} / 1$ & $250 \mathrm{ml} / 1$ & $500 \mathrm{ml} / 1$ \\
\hline \multicolumn{8}{|l|}{ SL2-900 } \\
\hline$M$ & 1 & 18.5 & ND & 2 & 1 & 2 & 1 \\
\hline CL & {$[0.5-1.5]$} & {$[2-35]$} & ND & {$[0.4-3.6]$} & {$[0.6-1.4]$} & {$[0.5-3.5]$} & {$[0-2.1]$} \\
\hline Results & & + & ND & - & - & - & - \\
\hline Toxicity & NT & NT & ND & NT & NT & NT & $\mathrm{T}$ \\
\hline \multicolumn{8}{|l|}{ SL2-3750 } \\
\hline$M$ & 1 & 18.5 & 1.5 & 2.5 & 3 & 1 & ND \\
\hline CL & {$[0.5-1.5]$} & {$[2-35]$} & {$[0-3.1]$} & {$[1.5-3.5]$} & {$[2-4]$} & {$[0-2.6]$} & ND \\
\hline Results & & + & - & + & + & - & ND \\
\hline Toxicity & NT & NT & NT & NT & NT & $\mathrm{T}$ & HT \\
\hline
\end{tabular}

Genotoxicity results are expressed as the values of the medians $M$ (number of micronucleated erythrocytes per thousand) and their $95 \%$ confidence limits [CL]. ND: Not determined. -: Negative results, no genotoxic effects detected in the tested groups. + : Positive results, genotoxic effects detected in the tested groups.

Toxicity results. HT: Highly toxic, all animals in the groups were dead. T: Toxic, all animals in the groups showed significant size reduction. NT: Not toxic, no toxicity observed in the groups. 
Table 4

Results of the FETAX test obtained with sludge S2, soil So and soil-sludge mixtures at different concentration levels, evaluated after aqueous extraction

\begin{tabular}{llllllll}
\hline & Negative control & Positive control & SoL & SL2-10 & SL2-30 & SL2-900 & SL2-3750 \\
\hline Number of embryos & $(32-119)$ & $(32-106)$ & 47 & 48 & 47 & 48 & 48 \\
\% Mortality & $(0-10.4)$ & $(0-3.1)$ & 2.1 & 4.2 & 4.3 & $100^{*}$ & $100^{*}$ \\
\% Malformation & $(0-9.4)$ & $(93.8-100)$ & 6.5 & 0.0 & 11.1 & ND & ND \\
Length (\% control) & 100 & ND & $92.72 *$ & $93.18^{*}$ & $93.78^{*}$ & ND & ND \\
\hline
\end{tabular}

Numbers in brackets represent the minimum and the maximum values observed in the experimental groups. *: Statistically different from the control group. ND: Not determined.

were not found in any other leachate tested. Most of the young larvae reared in leachate SL2-900, at $250 \mathrm{ml} / 1$, showed a typical rolling up of the spinal cord. This malformation was also observed in some embryos reared in leachate SL2-3750, at $125 \mathrm{ml} /$ 1.

Concerning the size of the animals, the differences between the mean lengths of the control larvae and those of larvae exposed to leachates SoL, SL2-10 and SL2-30 were statistically significant. Likewise, the non-lethal dilutions of leachate SL2-900 induced significant size reduction at 83.3, 125 and $166.7 \mathrm{ml} / \mathrm{l}$. The leachate had to be diluted to $62.5 \mathrm{ml} / 1$ in order to induce normal growth, comparable to that of the negative control. At the same concentration, leachate SL2-3750 resulted in a significant reduction of length in Xenopus embryos.

\subsection{Bioassay using the tobacco plant Nicotiana tabacum L. var. xanthi Dulieu}

Six concentrations of the following materials were prepared and tested, including the control: the sludge from the second supply S2 (S2-3750), the agricultural soil (So) and four soil-sludge mixtures equivalent to the concentrations of $30 \mathrm{t} /$ ha $(\mathrm{S} 2-30), 90 \mathrm{t} / \mathrm{ha}(\mathrm{S} 2-90), 300 \mathrm{t} / \mathrm{ha}(\mathrm{S} 2-300)$ and $900 \mathrm{t} / \mathrm{ha}$ (S2-900).

After the first 5 days, most of the tobacco plants cultivated in sludge S2-3750 and in mixture S2900 had died. After replacement by new young tobacco plants, only a few survived at these two concentrations. Among the surviving plants, some were cultivated for 56 days and compared to the tobacco plants cultivated in soil (So) during the same period. The tobacco plants cultivated directly in the sludge showed a very strong reduction in size compared to the plants that grew in the control soil. No particular size reduction was observed with the other concentrations tested. The reversion rates were estimated on groups of 18 plants cultivated under the conditions of treatment over a period of 45 days (Table 6). The mean reversion rates increased with the concentration of sludge added to the soil, but no statistically significant differences were found, compared to the control.

\section{Discussion-conclusion}

\subsection{The micronucleus assay on Xenopus larvae}

The results obtained in the second experiment confirm those of the first one, where genotoxicity was detected in the leachates of the sludge even after dilution. In the later experiment, the dilution of the sludge was of two sorts: first, dilution with agricultural soil and, second, dilution of the mixture leachate with water before testing. The lowest sludge concentration tested (SL-10), equivalent to a $10 \mathrm{t} / \mathrm{ha}$ amendment, did not lead to any positive response, whereas the concentration of $30 \mathrm{t} / \mathrm{ha}$ (SL-30) led to a clearly positive response in the test. This concentration is the French legal maximum concentration of sludge for land use, over a period of 10 years. At the highest concentration tested $(900 \mathrm{t} / \mathrm{ha})$, the leachate resulted in the rapid death of the animals and thus needed to be diluted in water before testing. The negative responses obtained could be attributed to the high toxicity of the original mixture, masking its potential genotoxicity after dilution in water. This hypothesis is corroborated by the low mitotic indices measured in the larvae. The same explanation could be given 
Table 5

Results of the FETAX test obtained with soil-sludge mixtures SL2-900 and SL2-3750 after water dilution

\begin{tabular}{|c|c|c|c|c|c|c|c|c|c|}
\hline & Negative control & Positive control & $62.5 \mathrm{ml} / 1$ & $83.3 \mathrm{ml} / 1$ & $125 \mathrm{ml} / 1$ & $166.7 \mathrm{ml} / 1$ & $200 \mathrm{ml} / 1$ & $250 \mathrm{ml} / 1$ & $500 \mathrm{ml} / 1$ \\
\hline \multicolumn{10}{|l|}{ SL2-900 } \\
\hline Number of embryos & $(32-119)$ & $(32-106)$ & 120 & 56 & 119 & 89 & 32 & 111 & 32 \\
\hline$\%$ Mortality & $(0-10.4)$ & $(0-3.1)$ & 3.3 & 0.0 & 0.0 & 1.1 & 12.5 & $79.3^{*}$ & $100^{*}$ \\
\hline$\%$ Malformation & $(0-9.4)$ & $(93.8-100)$ & 5.2 & 7.1 & 10.9 & 13.6 & 10.7 & $100^{*}$ & ND \\
\hline Length ( $\%$ control) & 100 & ND & 99.21 & $97.75^{*}$ & $93.75^{*}$ & $84.29 *$ & ND & ND & ND \\
\hline \multicolumn{10}{|l|}{ SL2-3750 } \\
\hline Number of embryos & $(32-119)$ & $(32-106)$ & 80 & 49 & 80 & ND & $\mathrm{ND}$ & 32 & 32 \\
\hline$\%$ Mortality & $(0-10.4)$ & $(0-3.1)$ & 3.8 & 6.1 & $43.8^{*}$ & ND & ND & $100 *$ & $100 *$ \\
\hline \% Malformation & $(0-9.4)$ & $(93.8-100)$ & 7.8 & 4.3 & 6.7 & ND & ND & ND & ND \\
\hline Length ( $\%$ control) & 100 & ND & $94.18^{*}$ & ND & ND & ND & ND & ND & ND \\
\hline
\end{tabular}

Numbers in brackets represent the minimum and the maximum values observed in the experimental groups. *: Statistically different from the control group. ND : Not determined. 
Table 6

Results of the Tobacco Somatic Mutation test

\begin{tabular}{lllll}
\hline & $S_{g}\left(\mathrm{~mm}^{2}\right)$ & $S\left(\mathrm{~mm}^{2}\right)$ & $d\left(\mathrm{cell} / \mathrm{mm}^{2}\right)$ & $p\left(\times 10^{5}\right)$ \\
\hline So & $2.01 \pm 0.70$ & $14274 \pm 930$ & 901 & $0.84 \pm 0.29$ \\
S2-30 & $2.03 \pm 0.77$ & $16831 \pm 3373$ & 769 & $0.67 \pm 0.12$ \\
S2-90 & $2.12 \pm 0.87$ & $16286 \pm 2522$ & 659 & $0.95 \pm 0.51$ \\
S2-300 & $2.53 \pm 1.27$ & $15906 \pm 3671$ & 671 & $1.05 \pm 0.46$ \\
S2-900 & ND & ND & ND & ND \\
S2-3750 & ND & ND & ND & ND \\
\hline
\end{tabular}

Mean values and their S.D. (mean \pm S.D.) obtained for the parameters measured in tobacco leaves at the various concentrations of soil-sludge mixture tested. $S_{g}$ : Total reverted area. $S$ : Total leaf area. $d$ : Cell density. $p$ : Reversion rate, ND: Not determined.

for the negative results obtained with the leachate of the sludge (SL-3750) at the highest concentrations tested. The soil leachate was not found to be genotoxic in our test system, confirming our initial choice of this crop soil for dilution use under agricultural conditions. The evaluation of toxicity towards Xenopus larvae seems to be a sensitive marker of the presence of the municipal sludge in the mixtures. Considering this parameter, the following classification could be proposed: SL$3750>$ SL-900 $>$ SL-30 > SL-10 > SoL.

The micronucleus test results demonstrate the ability of the Xenopus larvae to reveal the genotoxic impact of a sludge through its aqueous extract, even after dilution. They also demonstrate the potential long-term effects of the municipal sludge tested on the aquatic compartment, when incorporated into an agricultural soil at the concentration of $30 \mathrm{t} / \mathrm{ha}$.

\subsection{The FETAX test}

The number of malformed embryos was not directly correlated to the theoretical quantity of sludge in the leachates tested. The two other parameters studied (mortality and growth inhibition) seem to be more relevant and sensitive indicators of the biological impact of sludge leachates on Xenopus. For instance, the highest mortality rates were logically observed in the most concentrated leachates (SL-3750 and SL-900) at the highest concentrations tested. These leachates showed a significant growth inhibition at nonlethal concentrations. These results are in agreement with those of Prati et al. (2000), who demonstrated the sensitivity of the growth inhibi- tion parameter compared to mortality and malformation. It is now generally accepted that growth inhibition may be more sensitive than other endpoints (Dawson and Bantle, 1987), so it can be used as an alarm test system when mortality or malformation do not give significant responses compared to the controls.

Larvae reared in the lowest leachate concentrations (SL-30 and SL-10), including the soil leachate $(\mathrm{SoL})$, showed significant signs of growth retardation. This later result raises the question of the 'soil history'. Brown et al. (1985) showed that the mutagenic activity of the soil was directly related to the past applications of biocides and fertilizers. According to these authors, direct mutagenicity detected in soils is directly related to an exogenous mutagenic source. When soil naturally produces mutagens (from plants and bacteria), these would generally represent the major source of indirect mutagenic activity in agricultural soils.

The FETAX results corroborates the previous toxicity responses observed with the micronucleus assay on Xenopus larvae concerning the potential toxic impact of the soil-sludge mixtures.

\subsection{The tobacco somatic mutation test}

Two hypotheses (not mutually exclusive) can be proposed to explain the strong growth retardation observed in the plants cultivated on sludge S2 and mixture S2-900: (i) toxicity of the sludge, which induces mortality in most of the young tobacco plants, (ii) rooting problems correlated with the dense and spongy structure of the substrate. The first assumption corroborates our previous toxicity results obtained with amphibian 
larvae and embryos. Nevertheless, using the tobacco plant model, we did not observe any genotoxic impact in plants cultivated at non-lethal sludge concentrations. To explain the negative reversion rates observed, four hypotheses can be formulated: (1) The sludge is not genotoxic to tobacco plants, (2) genotoxic compounds in the sludge are not directly available for the plants, (3) genotoxic substances in the substrate are not transferred to the target in the leaves, (4) the threshold of action for genotoxic substances has not been reached in the plant. Some of these hypotheses have been tested in the laboratory. For instance, chemical analysis of the leaves and stems of tobacco plants grown for 63 days on mixture S2-90 revealed the metallic $(\mathrm{Zn}, \mathrm{Hg})$ and organic (PCB, HAP) contamination of the plants (particularly the leaves) compared to a control group. This observation seems to confirm the bio-availability and transfer of some potentially genotoxic substances from the sludge to the plant. Furthermore, we found no particular differences in growth-related parameters (stem elongation, leaf area, leaf number, cell density, biomass) measured on tobacco plants cultivated on mixture S2-90, compared to the control. The agronomical parameters measured and the genetic results obtained on tobacco plants raise the question of the sensitivity of the bioassay applied to the detection of the genotoxic impact of sludge in agriculture.

\subsection{Comparison of the bioassays used in this study}

Most of the studies focusing on the evaluation of the genotoxic impact of sludges used in vitro mutagenicity test systems, such as the Ames test and show low or no mutagenic activity (Hopke et al., 1982; Babish et al., 1983; Ottaviani et al., 1993). Sludge-amended soils (Donnelly et al., 1988, 1990; Davol et al., 1989) and agricultural soils (Brown et al., 1985) have also been studied using the Ames bacterial assay. In previous studies (Van Der Gaag et al., 1990), we demonstrated the main advantages of in vivo test systems to predict the impact of genotoxins in environmental studies. The same approach was adopted in the present work to judge of the potential genotoxic and teratogenic impact of sludge in our environment. For this, animal and plant bioassays were applied together in a test battery to compare the ability of direct testing systems (Xenopus and tobacco) to detect the genotoxic potential of a municipal sludge and to estimate its potential genetic impact when incorporated into an agricultural soil as fertilizer. Thus, this battery of in vivo tests allows one to estimate the global long-term effects under agricultural conditions with various genetic endpoints (reverse mutations, chromosomal aberrations and teratogenic effects) on ecologically relevant organisms.

Our two biological models present some fundamental testing differences that can help to explain the different sensitivities in the responses observed. Using the amphibian aquatic model, young larvae and embryos are directly exposed to a leachate produced from the substrate sample to be tested. Aqueous extraction represents a very vigorous process compared to natural events taking place in an agricultural soil in the natural environment. Its effects could be compared to those of drastic rainfalls on land parcels. Under these conditions, potentially genotoxic substances absorbed on the organic-mineral fraction of the soil may be dissolved and thus express their genetic effects in water-exposed organisms, even at low concentrations. Aqueous extraction, as used in this study, gives an approximation of the 'maximum hazard' that a contaminated substrate represents for the aquatic compartment (Bekaert, 1999). In this way, the amphibian micronucleus test and the FETAX assay seem to be very sensitive methods suited to an evaluation of the global genotoxic and teratogenic potential of soils and sludge with respect to the aquatic environment.

In the tobacco somatic mutation test, the entire plant is cultivated directly on the substrate to be tested. In this case, experimental conditions mimic the actual field conditions and may, therefore, be more justifiably extrapolated to agricultural situations. Agrochemical parameters, especially soil composition, interfere with the direct expression of the genotoxicity at the soil-plant interface. The soil diluent used in our experiments is a clay-like soil with a pH between 6.9 and 7.2. Such $\mathrm{pH}$ is known to inhibit the assimilation by plants of 
pollutants such as metals (Van Loon, 1974). Lipophilic compounds are easily adsorbed on the organic fraction of the soils and are not easily absorbed by the roots (Dean and Suess, 1985; O'Connor et al., 1991). Moreover, clay-like soils have a strong retention capacity, meaning that these compounds are strongly adsorbed on particulate matter, including any potentially genotoxic contaminants. Finally, these soils are very favorable supports for the development of bacteria necessary to degrade organic compounds in soils, including those brought by the sludges. Degradation of potentially mutagenic substances occurs more easily in claylike soils than in others (Donnelly et al., 1988). These factors, as a whole, may have contributed to the observation of negative responses in our experiments using the tobacco plant model. More generally, these results raise the question of the suitability of the model for revealing the presence of genotoxic substances in an agricultural soil.

Compared to the amphibian genotoxicity tests used in this study, the exposure protocol for the tobacco requires the transfer of active compounds through the plant before any reverse mutagenic effects can be observed in the leaves. With amphibian larvae, the potential mutagenic source is directly in contact with the tested organism, so that the biological impact is more easily detected. Before testing soil and sludge samples, we demonstrated the ability of the tobacco mutation test to reveal the mutagenicity of a soil contaminated with various concentrations of a well-known mutagenic compound: ethyl methane sulfonate (Chenon, 2001). In the framework of this study, the low concentrations of contaminants measured in the sludge and in the mixtures may have contributed to preventing the potential genotoxic substances from reaching the target in the plant. More generally, our results provide matter for reflection on the sensitivity of the tobacco plant model and the relevancy of the amphibian model, associated in a test battery, to judge the genotoxic impact of sludge amendment in agriculture.

\section{Acknowledgments}

This work was supported by the French Agency for the Environment and Energy Resources (ADE-
ME) as part of a coordinated research project and by the National Institute for Industrial Environment and Risks (INERIS). We are greatly indebted to Antonio Bispo and Marie-Josée Jourdain from IRH-Environment Nancy-France, for the physicochemical analysis. The authors are very grateful to Sylvie Laloubère and Caroline Mouysset for technical help and to Giovani Bernardini, Claudio Vismara and Hubert Dulieu for their help in field work. Thank you to Julian Smith for reviewing the manuscript.

\section{References}

AFNOR. NF T90-325 Qualité de l'eau-Evaluation de la génotoxicité au moyen de larves d'amphibiens (Xenopus laevis, Pleurodeles waltl). 2000.

AFNOR. X31-210 Déchets. Essai de lixiviation. 1992.

Ames BN, Mac Cann J, Yamasaki E. Methods for detecting carcinogens and mutagens with Salmonella/mammalian microsome mutagenicity test. Mutat Res 1975;31:347-363.

Babish J, Jonhson B, Lisk D. Mutagenicity of municipal sewage sludges of American cities. Environ Sci Technol 1983;17:272-277.

Bekaert C. Impact écotoxicologique de sols pollués et de déchets sur le compartiment aquatique. Thèse de l'Université Paul Sabatier, Toulouse, France 1999.

Bernardini G, Vismara C, Boracchi P, Camatini M. Lethality, teratogenicity and growth inhibition of heptanol in Xenopus assayed by a modified frog embryo teratogenesis assayXenopus (FETAX) procedure. Sci Total Environ 1994;151(1):1-8.

Brown K, Donnelly K, Thoma J, Davol P, Scott B. Mutagenicity of three agricultural soils. Sci Total Environ 1985;41(2): 173-186.

Chenon P. Evaluation du pouvoir toxique, génotoxique et tératogène de boues de stations d'épuration valorisées en agriculture. Thèse de l'Université Paul Sabatier, Toulouse, France 2001.

Davol P, Donnelly K, Brown K, Thomas J, Estiri M, Jones D. Mutagenic potential of runoff water from soils amended with three hazardous industrial wastes. Environ Toxicol Chem 1989;8:189-200.

Dawson D, Bantle J. Development of a reconstituted water medium and preliminary validation of the frog embryo teratogenesis assay-Xenopus (FETAX). J Appl Toxicol 1987;7(4):237-244.

Dean R, Suess M. The risk to health of chemicals in sewage sludge applied to land. Waste Manage Res 1985;3:251-278.

Delpoux M, Dalebroux M. Genetic effects on the $a 1+/ a 1$ $a 2+/ a 2$ system of tabacco over a uranous outcrop in the permian basin of Lodeve (Herault, France). Mutat Res 1981a;82:101-110. 
Delpoux M, Dalebroux M. Genetic effects on the $a 1+/ a 1$ $a 2+/ a 2$ system of tobacco over a uranous outcrop in Lauragais (Aude, France). Mutat Res 1981b;83:375-382.

Devaud B. Evaluation in situ des effets génétiques d'atmosphères diversement polluées de l'agglomération de Toulouse. Thèse de l'Université Paul Sabatier, Toulouse, France 1986.

Donnelly K, Brown K, Chisum C. Mutagenic potential of municipal sewage sludge and sludge amended soil. Chemical and biological characterization of sludges, sediments, drege spoils and drilling muds. In: Lichtenberg JJ, Winter JA, Weber CI, Fradkin L, editors. ASTM STP 976, American Society for Testing and Material Philiadelphia 1988. p. 288 299.

Donnelly K, Thomas J, Anderson C, Brown K. The influence of application rate on the bacterial mutagenicity of soil amended with municipal sewage sludge. Environ Pollut 1990;68:147-159.

Dulieu H. Somatic variations on a yellow mutant in Nicotiana tabacum L. $(a 1+/ a 1 a 2+/ a 2)$. II Reciprocal genetic events occurring in leaf cells. Mutat Res 1975;28:69-77.

Dulieu H, Dalebroux M. Spontaneous and induced reversion rates in a double heterozygous mutant of Nicotiana tabacum var. xanthi n.c.-dose response relationship. Mutat Res 1975;30:63-70.

Fabries M, Delpoux M. Genetic effects of low and very low chronic doses of gamma-irradiation on the $a 1+/ a 1 a 2+/$ $a 2$ system of tobacco. Mutat Res 1978;49:377-382.

Gauthier L. The amphibian micronucleus test, a model for in vivo monitoring of genotoxic aquatic pollution. Int $\mathrm{J}$ Batrachol 1996;14(2):53-84.

Gauthier L, Van der Gaag M, L'Haridon J, Ferrier V, Fernandez M. In vivo detection of waste water and industrial effluent genotoxicity: use of the newt micronucleus test (Jaylet test). Sci Total Environ 1993;138:249-269.

Hopke P, Plewa M, Johnston J, Weaver D, Wood S, Larson R, Hinesly T. Multitechnique screening of Chicago municipal sewage sludge for mutagenic activity. Environ Sci Technol 1982;16(3):140-147.

Jaylet A, Zoll C. Tests for detection of genotoxins in freshwater. Aquat Sci 1990;2(2):151-166.

Klöpffer W. Environmental hazard assessment of chemicals and products: Part V. Anthropogenic chemicals in sewage sludge. Chemosphere 1996;33:1067-1081.

Maron D, Ames B. Revised methods for the Salmonella mutagenicity test. Mutat Res 1983;6:669-681.
Mac Gill R, Tuckey J, Larsen W. Variations of box plots. Am Statist 1978;32:12-16.

Nieuwkoop P, Faber J. Normal table of Xenopus laevis. Amsterdam: Daudin, 1956.

O'Connor G, Chaney R, Ryan JA. Bioavaibility to plants of sludge-borne toxic organics. Rev Environ Contam Toxicol 1991;121:129-155.

Ottaviani M, Crebelli R, Fuselli S, La Rocca C, Baldassarri L. Chemical and mutagenic evaluation of sludge from a large wastewater treatment plant. Ecotoxicol Environ Saf 1993;26(1):18-32.

Prati M, Biganzoli E, Boracchi P, Tesauro M, Monetti C, Bernardini G. Ecotoxicological soil evaluation by FETAX. Chemosphere 2000;41(10):1621-1628.

Van Der Gaag M, Gauthier L, Noordsij A, Levi Y, Wrisberg M. Methods to measure genotoxins in waste water: evaluation with in vitro and in vivo tests. In: Waters MS, Daniel FB, Lewtas J, Moore MM, Nesnow S, editors. Genetic toxicology of complex mixtures: short term bioassay in the analysis of complex environmental mixtures. New York: Plenum Press, 1990. p. 215-232.

Van Hummelen P, Zoll C, Paulussen J, Kirsch-Volders M, Jaylet A. The micronucleus test in Xenopus: a new and simple 'in vivo' technique for detection of mutagens in fresh water. Mutagenesis 1989;4(1):12-16.

Van Loon J. Mercury contamination of vegetation due to the application of sewage sludge as fertilizer. Environ Lett 1974;63:211-218.

Weaver D, Hopke J, Johnson J, Plewa M. Mutagenicity of Chicago municipal sewage sludge in the Salmonella microsome reverse mutation assay. Environ Mutagen 1981;3:350356.

Zoll C, Ferrier V, Gauthier L. Use of aquatic animals for monitoring genotoxicity in unconcentrated water samples. In: Kappas A, editor. Mechanisms of environmental mutagenesis-cargenesis. New York: Plenum Press, 1990. p. $233-$ 244.

Zoll-Moreux C. Conséquences de la contamination du milieu hydrique par les sels de mercure, du benzo(a)pyrène ou des pesticides organochlorés, chez deux amphibiens Pleurodeles waltl et Xenopus laevis. Thèse de l'Université Paul Sabatier, Toulouse, France 1991.

Zoll-Moreux C, Ferrier V. The Jaylet-Test (newt micronucleus test) and the micronucleus test in xenopus: two in vivo tests on amphibia. I. Evaluation of the genotoxicity of five environmental pollutants. II. Evaluation of the genotoxicity of five effluents. Water Res 1999;33:2301-2314. 